\title{
BCLAF1 wt Allele
}

National Cancer Institute

\section{Source}

National Cancer Institute. BCLAF1 wt Allele. NCI Thesaurus. Code C115995.

Human BCLAF1 wild-type allele is located within 6q22-q23 and is approximately $33 \mathrm{~kb}$ in length. This allele, which encodes $\mathrm{Bcl}-2$-associated transcription factor 1 protein, plays a role in both apoptosis promotion and the repression of transcription. 